\title{
Homonationalism in teacher education - productions of schools as heteronormative national places
}

\author{
Eva Reimers
}

Journal Article

\section{Tweet}

N.B.: When citing this work, cite the original article.

This is an electronic version of an article published in:

Eva Reimers, Homonationalism in teacher education - productions of schools as heteronormative national places, Irish Educational Studies, 2017. 36(1), pp.91-105. Irish Educational Studies is available online at informaworldTM:

http://dx.doi.org/10.1080/03323315.2017.1289703

Copyright: Taylor \& Francis (Routledge): SSH Titles http://www.routledge.com/

Postprint available at: Linköping University Electronic Press

http://urn.kb.se/resolve?urn=urn:nbn:se:liu:diva-137102

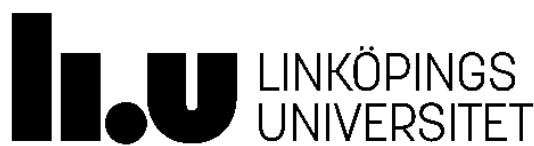




\title{
Homonationalism in Teacher Education - Productions of Schools as Heteronormative National Places
}

Eva Reimers

Linköping University

\begin{abstract}
The paper interrogates how teacher education and schools are produced as places for simultaneous and intertwined norms of nationality and norms of sexuality. Drawing on data from observations at a Swedish teacher training programme, the concepts of banal nationalism, homonationalism, and precarity are used in order to discuss productions of sexual, national, and cultural subjects. The analysis indicates that homonationalism in education produces tolerable queers together with intolerant migrants. In this way Sweden is produced as a homonormative nation in opposition to nations and subjects that are considered 'other'. The concluding section suggests using investigations of homonationalism as a tool in teacher education in order to bring about more inclusive schools.
\end{abstract}

Key-words: teacher education, homonationalism, LGBTQI

\section{Introduction}

This paper draws upon data generated in a Swedish teacher training programme to interrogate the ways in which teacher education and schools are produced as places for simultaneous and intertwined norms of nationality and norms of sexuality. In the paper I use the concept of homonationalism (Puar 2007) in order to shed light on how norms about sexuality produce schools as simultaneously heteronormative and national spaces, and some subject positions, and bodies, as more vulnerable and precarious than others (Butler 2015).

The first part contextualises the article by giving a short review of Swedish legislation and the national compulsory school curriculum in relation to LGBTQI issues and persons, as well as a review of some research that I find important in relation to LGBTQI and education. Subsequently, I describe my theoretical perspective, which is inspired by Jasbin Puar's concept of 'homonationalism' (Puar 2007, 2013), Judith Butler's writings on 'liveable 
lives’ and 'precarity’ (Butler 2004, 2015), and Michael Billig's concept of 'banal nationalism' (Billig 1995). Common for these concepts is that they all are founded on a critique of the effects of neoliberalism in relation to democracy, solidarity, how to make sense of diversity. In the second part of the article I present and discuss observations from a study of norms on sexuality and nationality in a Swedish teacher education programme. Drawing on Puar, Billig, and Butler, I argue that reiterations and productions of LGBTQI norms in teacher education are entangled with productions of nationalism, race, and culture, affirming 'the Swedish' as liberal, modern, and secular and 'the non-Swedish' as conservative, obsolete, and religious. I conclude the article by discussing possible consequences of homonationalism in education in relation to production of precarious subjectivities.

\section{Swedish sexual politics and education}

Swedish policy and legislation concerning LGBTQI persons are based on and reiterate liberal discourse about human rights and the benefits of social diversity. The rights discourses are prevalent in legislation, which stresses the right of everyone not to be discriminated against. The diversity discourses are articulated in discourses which focus on mixing different forms of identity categories in order to bring about creativity and economic growth (cf. Martinsson and Reimers 2008). LGBTQI-identified persons are included in the legislation against discrimination in working life and education, which states that it is illegal to discriminate against employees, students in higher education, and pupils in compulsory education on the grounds of sexual or gender identity. Sexual and gender identity are also included in the legislation against incitement of hatred, or hate crimes. Besides this legislation which protects the rights of LGBTQI persons, in the past three decades LGBTQI persons have been granted rights they did not have previously. Today, marriage legislation is gender-neutral, same-sex couples are eligible to adopt children, the right to in-vitro fertilisation (IVF) now also includes lesbian couples, and transgender people no longer have to be sterilised in order to be granted a physical sex change. Furthermore, lesbians, transsexual persons, and, especially, gay men appear in the media as authors, artists, singers, politicians, and journalists. Based on this, one might infer that LGBTQI persons in Sweden are more or less equal to heterosexuals, and that identifying as LGBTQI is no big deal. However, as will be demonstrated in this paper, even if the situation for queers in Sweden is better than in many other places, it is still stigmatising to identify as homosexual, bisexual, transgender, intersexual, or queer. Despite favourable legislation and a dominant discourse of tolerance, LGBTQI identification is still 
considered a deviation. The official norm of (homo)tolerance pertains also to compulsory education. The beginning of the Swedish Education Act as well as the National Curriculums for preschool to upper secondary school (SFS 2010:800, Skolverket 2011) reiterate the formulations in the legislation against discrimination, stating:

No one should be subjected to discrimination on the grounds of gender, ethnic affiliation, religion or other belief system, transgender identity or its expression, sexual orientation, age or functional impairment or other degrading treatment. Such tendencies should be actively combated. Xenophobia and intolerance must be confronted with knowledge, open discussion and active measures. (Skolverket 2011, 9)

At the same time as this reiteration of the legislation against discrimination can serve as a protection for LGBTQI-identified persons, the naming of specific categories as at risk of being discriminated against constructs some bodies as more vulnerable than those belonging to the (unnamed) majority. In being named as in need of special legal protection, LGBTQI persons are simultaneously constructed as more exposed than the unnamed heterosexual and cis-gender majority. This points to a dilemma in all forms of politics of recognition in the interest of subaltern or marginalised groups or categories. In order to bring about change, the categories have to be recognised as being suppressed or deprived of equal rights. However, in being recognised, categories such as LGBTQI persons are constructed both as stable and homogeneous, and as 'other' and deviant in relation to an unproblematised majority. The national curriculum partly addresses this problem in relation to gender and sexuality in one of the paragraphs under the heading 'An equivalent education'.

In that paragraph, the curriculum states that the school should actively and consciously further equal rights and opportunities for women and men. The way in which girls and boys are treated and assessed in school, and the demands and expectations that are placed on them, contributes to their perception of gender differences. The school has a responsibility to counteract traditional gender patterns. It should thus provide scope for pupils to explore and develop their ability and their interests independently of gender affiliation (Skolverket 2011, 10). In this passage teachers are made responsible to 'counteract traditional gender patterns'. From a queer perspective focused on how heterosexual norms produce queerness as deviance (cf. Butler 1990; Rich 1993; Warner 1993), one could argue that this is an appeal to subvert not only stereotypical gender norms, but also sexuality norms. As Butler has convincingly argued, gender and sexuality norms are always intertwined, because it is by 
drawing on sexuality that gender is constructed and vice versa (Butler 1990, 1993). In order to counteract 'traditional gender roles' the teachers therefore need to question why and how dominant gender roles prescribe that men should desire women and women should desire men. 'Queering' thus becomes a pedagogical tool used to fulfil the requirements of the curriculum (Reimers 2008).

Based on the legislation and the formulations in the Education Act and National Curriculum, one might infer that identifying as lesbian, gay, bisexual, intersexual, or transgender would be no problem in Swedish schools or in teacher education. One motivation for the research project on which this article is based, however, was the conspicuous absence of self-identified and openly LGBTQI teacher students at the university where I was teaching, as well as the absence of openly self-identified LGBTQI teachers where the students did their practicum (cf. Lundgren 2008, Sahlström 2006).

The invisibility of LGBTQI bodies in schools, regardless of country, is well established. From a British perspective, Epstein and Johnson describe schools as spaces where sexuality is both nowhere and everywhere (Epstein and Johnson 1998, 108). As they convincingly demonstrate, the presumption of sexuality as an irrelevant component for teacher and student subjectivities enforces rather than subverts the heterosexual norms. Due to the entanglement of gender and sexuality norms, the gender norms that pupils and teachers are expected to adhere to reiterate conceptions of gender based on a dichotomous relation between femininity and masculinity simultaneously encompassing homo-social and heterosexual desires. As a heterosexual girl (pupil), or woman (teacher), one is expected to befriend other girls and women and to form intimate relationships with boys or men. Acts that transgress these patterns not only stand out, they are also questioned and, in various ways, punished (cf. Allan et.al. 2010; Bengtsson 2013; Epstein and Johnson 1998; Epstein et al. 2003). In this way schooling tends to enforce and stabilise heterosexual gender norms at the expense of other ways of performing gender and sexuality. A study of sex education in Norway indicates that this reproduction of heteronormativity continues regardless of a general tolerance and acceptance of queer lifestyles as well as support for judicial equality (Røthing 2008). By centring the teaching on the goal of making a presumed present heterosexual 'us' tolerant of a presumed absent homosexual 'them', the classroom is constituted as a heterosexual space producing heterosexuality as both taken for granted and invisible. Røthing uses the term 'homotolerance' to make trouble with how teaching tolerance of LGBTQ subjects in this way enforces heteronormativity, a term that is also 
highly applicable to the situation in Sweden. Similar results were elicited in a study of Australian teachers identifying themselves as lesbian. Ferfolja (2007) found that despite more than 30 years of anti-discrimination legislation, many lesbian teachers still feel compelled to manage their sexuality in the workplace through self-regulation and monitoring in order to pass as heterosexual, and therefore appropriate teachers (see also Cavanagh 2005, 2006; King 2004, Lundgren 2008; Luschen and Bogad 2003). Research on how LGBTQI issues are addressed in teacher education points to the hegemony of heteronormativity in a very similar way as in studies of schools. From a US perspective, Kissen (2002) maintains that little is done in teacher education to advance knowledge about LGBTQI issues among future teachers. This is confirmed by Sherwin and Jennings (2006), who argue that secondary teacher programmes are very likely to sustain homophobic schools by failing to teach about LGBTQI issues. Schools are consequently spaces where heterosexual norms are reproduced and other gender and sexual subject positions than the heterosexual are marginalised.

Gender and sexuality norms are never articulated and performed in isolation. They always intersect with other norms (cf. Kumashiro 2001), not least with what can be understood as the meta-narrative in education, that is, the narrative about nationality. Schools are national institutions and thereby means to enhance shared values and keep society together. Epstein and Johnson (1998) as well as Reimers $(2007,2008)$ have pointed to how this implies intersections, or rather entanglements, of sexuality and nationality in education. The two citations above from the Swedish national curriculum are both found in the introductory section under the heading 'Fundamental values and tasks for the school'. In another paragraph it is also stated: 'Education should impart and establish respect for human rights and the fundamental democratic values on which Swedish society is based' (Skolverket 2011, 9). Learning and internalising these 'fundamental values' is consequently a central aspect of becoming and being a Swedish citizen. Furthermore, as institutions that reach all inhabitants, schools represent one of the most important spaces for constructions of nationality and nationhood. In school one not only learns certain subjects, one also learns what it is to be a person and a national citizen. This is why there are links between sexuality, the nation, and the school. As Epstein and Johnson argue, '...national identity, in general can best be understood as a “nationalisation” of other social identities' (Epstein and Johnson 1998, 18). This is also the reason why Røthing (2008) writes about 'homotolerance' not just as a position or attitude within education, but as a signifier of what is apprehended as Norwegian. 
The invisibility of LGBTQI bodies and subject positions within schools and teacher education together with a nationalised heteronormativity in combination with (homo)tolerance produce not only LGBTQI bodies as deviant 'others', but also categories of homophobic 'others' as separate and radically different from a tolerant national 'us'. In order not to marginalise pupils, teachers, and care-givers, based either on gender and sexuality or on race and ethnicity, it is important to develop knowledge on how marginalisation and homogenisation are produced in education. Considering the impact and power of teachers in how norms are reiterated and enacted in schools, the task for this paper is to scrutinise the entanglements of sexuality, nationality, and tolerance in Swedish teacher education.

\section{Theory - Homonationalism, banal nationalism, and precarious subjects}

In his seminal book Banal Nationalism, Billig (1995) argues that the notion that the spatial world is self-evidently organised on the basis of nation-states making all physical spaces into national places also encompasses the idea of nationality as national citizenry, as national characteristics of collectives connected to places designated as nations. The term 'nation' consequently encompasses two different but highly enmeshed meanings: on the one hand, the 'nation' as the nation-state, and on the other hand, the 'nation' as the people living in the nation-state (Billig 1995, 24). Neither of these conceptions of the nation are founded on socalled 'objective criteria’ (cf. Anderson 1983). There are no obvious or given reasons why all places have to belong to nations, or why the people living in these nations should be bound together by common interests, habits, or culture. In order for the two conceptions of nation to gain force they have to be made real through performative practices of repetition. These practices are what Billig names 'banal nationalism'. The idea is not that these practices are banal in the sense that they are of little importance, rather the opposite. The term 'banal' refers to how conceptions of nations and nationalism are reproduced in banal or mundane ways, how they serve as a backdrop and prerequisite for thinking, talking, and organising societies and lives, without actively naming nationalism. This is not least evident in compulsory education.

In most countries, compulsory education is a national project aiming to foster citizens and create prerequisites for a prosperous future for the nation as a collective. This is one reason why the Swedish national curriculum begins with accounts of what 'fundamental values' the school is supposed to be based on and convey to the (future) citizens. All subjects and activities in the schools can therefore be seen as practices of banal nationalism, where choices of subject matter, forms of pedagogy, architecture of the buildings, organisation of 
the semester and the school days, assessment practices, and so forth are articulations and performances of what signifies the nation Sweden. The overarching goal for any national school system is thus schooling in nationalism. One example of how educational practices are founded on and enmeshed with nationalism is found in Schooling sexualities (Epstein and Johnson 1998), where Epstein and Johnson convincingly show that constructions of nationality can be viewed through the lens of sexuality, because sexual components are always embedded in national discourses, and vice versa (ibid., 5).

I have found the analytical concept 'homonationality' (Puar 2007, 2013) useful for analysing the entanglements of sexuality and banal nationalism. Puar developed homonationalism as an analytical concept to understand the desirability of representing nations as 'gay-friendly'. It is founded on the observation that sexuality has become increasingly used by Western countries in order to construct proper citizens as tolerant of queer liberal subjects. One example of this already mentioned is the 'homotolerance' that Røthing observed in Norwegian sex education (Røthing 2008), where tolerance of lesbian, gay, bisexual, and queer subjects was constituted as significant for Norwegian citizens. Using the two concepts - banal nationalism and homonationalism- together, homonationalism can be seen as an effect of homotolerant heteronormativity as a signifying trait of a nation-state. In this way, the queer liberal subjects, that is, white, liberal, tolerant, consumer-oriented LGBTQI subjects, contribute to processes of sexual othering. The rights of LGBTQI subjects, as tolerated white 'others', are enforced at the expense of racialised, obsolete, religious (often Muslim), homophobic 'others'. The concept of homonationalism can thus be seen as a critique of a liberal LGBTQI rights agenda focused on the inclusion of individual LGBTQI subjects within heterosexual normativity, rather than on subversions of the national sexual hegemony. According to Puar, the conception of LGBTQI subjects within the framework of rights discourses iterates a liberal normativity where subjectivity is based on individualism, rationality, and free choice (Puar 2007, 22-24, 51). An important aspect of homonationalism is how it disciplines and normalises queer bodies. It is thus not only heteronormative, but also homonormative. There are clear limitations to what is to be understood as tolerable and recognised normal LGBTQI subjectivity (cf. Seidman and Meeks 2011).

In order to elucidate processes of homonationalism, Puar suggests a move from intersectionality to assemblage. This is also how I conceive of homonationalism in this paper. This is not to disparage intersectional studies. Several researchers in the field of education and sexuality have done useful studies by employing intersectional perspectives. One 
example is Kumashiro (2001). By looking into intersections of race and sexuality and combining Critical Race Theory and Queer Theory, Kumashiro points to how a focus on gays and lesbians in education risks reiterating homosexuality together with whiteness and thereby obfuscating gays and lesbians of colour. There are, however, differences between using a perspective of intersectionality and a perspective of assemblage when the interest is in investigating productions of nationalism and sexuality. Where intersectionality presumes more or less stable norms and categories, the concept assemblage (cf. Deleuze \& Guattari 1987) do not presume stability or given norms and categories. Assemblages appear as networks of relations of norms and practices producing affects, emotions, and energies, as these networks inhabit events, places, and bodies (Puar 2005, 127-128). In studying queerness as emergences from assemblages, there is no identity to queer, no essentially queer bodies or subjects. The analytical concept of homonationalism as an assemblage is thus useful in that it can help with understanding the power of homonationalism in the production of sexual nationalism and sexual citizens as well as the production of that and those that are positioned as outside of or other in relation to the nation.

In discussing what is produced as outside of and other in relation to the nation, I draw on Butler's elaborations of the analytical concepts of precarity, vulnerability, recognition, and human life as a condition of interdependency (Butler 2015). Like Puar, Butler describes emergences of bodies as subjects as effects of networks. She critiques intersectionality, stating that persons are not collections of identities, but assemblages, produced and made possible by infrastructures, entities, elements, materialities, and bodies that they relate to (Butler 2015, 68). Before I develop my understanding of these concepts, I believe it is important to stress that the way assemblages of homonationalism produce subjects as 'other' is not limited to discourses or norms as language or ideas. Discourses and norms are material, they are what I have elsewhere described as normative materialisations (Martinsson and Reimers 2014). The othering of bodies or subjects by homonationalism has tangible economic, material, and political effects for the possibilities of living liveable lives (Butler 2015, 21). It is in recognition of this that Butler uses the concept of precarity not as an identity position or category but as a social and economic condition, where certain populations are made more exposed to injury, violence, and death than others. The concept is based on the notion that a fundamental condition for all beings is interdependence, because they(we) emerge through and in networks or assemblages. This implies vulnerability; nobody can sustain herself alone. In neoliberal times such as the present, where there is a stress on 
autonomous individuals and meritocracy as an outcome of rational choices, as if all beings were independent and detached from what Butler calls 'infrastructural support' (Butler 2015, 148), processes of precarisation tend to become naturalised.

Common for Puar and Butler is the role of neoliberalism as an important element in the assemblages that produce homonationalism and precarious bodies. This notion is productive also for the analyses in this paper. Drawing on Wendy Brown, neoliberalism is here seen both as a distinctive mode of reason and as a shifting signifier (Brown 2015). In stressing and naturalising economic values and rationales as dominant for every sector of society, not the least schooling, neoliberal governance simultaneously produces a conception of subjectivity as individual and rational (Brown 2015). School results and life trajectories are not only regarded as matters of making the right choices and thereby accessible for all (cf. Ball 2006). They are also seen as independent of social background, gender, race, sexuality and so forth. They way in which subjects are differently positioned, forming different possibilities and circumscriptions, is denied or made irrelevant. In the relation to this paper, that the precarity of LGBTQI students and teachers is concealed within a liberal discourse which only recognises individuals, disregarding the consequences of normative categorisations.

In the following I will put the analytical concepts 'banal nationalism', 'homonationalism', and 'precarity' to work in analysis of examples from Swedish teacher education, and hereby elucidate how homonationalism produces precarious conditions for some bodies, making some lives more liveable than others.

\section{Data generation and analysis}

The data for this paper was produced by participant observations at a Swedish teacher education college in a course titled 'Intersectionality and Cultural Diversity' and at a theme day titled 'Obstacles, Limitations, and Possibilities for Integrating LGBT Perspectives in School and Education'. Data consist of field notes, interviews, course material, and exam papers. For this paper, I predominantly draw on field notes. The students in the course and at the theme day were studying to become teachers at different levels of the school system. There were representatives of future teachers from K-12. I do not claim that what I present here necessarily represents practices in all 26 teacher training programmes in Sweden, but the discussion may be illustrative for other teacher training programmes as well. All teacher training in Sweden is based on the same governmental statutes, and all programmes aim to 
prepare their students to work in schools that base their work on the aforementioned 'Fundamental values and tasks of the school' (Skolverket 2011). Similar notions of the role of the teacher and her/his assignment are consequently likely to be repeated in all 26 teacher training programmes.

I will put the concept of homonationalism to work and show how it has contributed to productions of different normative as well as precarious bodies. The analysis can broadly be described as discourse analysis focused on how norms and subjectivities are discursively constructed. First I will focus on productions of tolerable LGBTQI subjects. Second, I will explore productions of the homophobic other, and third, I will account for productions of migrants as homophobes. In the analysis, categories such as gender, sexuality, and nationality, which in real life are inseparable, are for analytical reasons partly treated as separate. In the final section I will bring the categories together and discuss how homonationalism in Swedish teacher education risks producing precarious subjects in relation to sexuality and the nation.

\section{Homonationalism - the other as a tolerable LGBTQI}

Both the course on intersectionality and the theme day framed their aims in terms of linking schooling with nationalism. Both made explicit references to the fundamental values referred to in the beginning of this paper. The National Curriculum and the Education Act, where the demand to uphold and pass on these values is formulated, are legal documents created by the Swedish government. Whenever the word 'school' is mentioned in these documents, it refers to compulsory education in Sweden as a national endeavour. The fundamental values should therefore be read as fundamental Swedish values. The practices in the course and the theme day - reading textbooks, discussing texts, and participating in value exercises - can thus be understood as practices of banal nationalism. In these practices some bodies emerged as selfevidently normal and given, whereas other bodies emerged as deviations.

It was apparent that although several of these practices explicitly aimed to make way for inclusion of queer bodies in the collective of the nation, the notion of LGBTQI persons that emerged from the practices were LGBTQI as 'others', as different, as deviations from a given and not really articulated heterosexual 'we'. Furthermore, when homosexuality was addressed, it was predominantly addressed as an identity category, not as sexuality.

In preparation for a seminar on 'Sexual norms and transgressions' the students had read a book titled People like Us (Mobacker 2003). Each chapter in the book is a portrait of a 
queer person. The book hereby presents a wide range of differently positioned (gender, race, class, religion, functionality) queer subjects. The intent is to represent queers as both diversified and as possible to identify with, or to put it another way, the aim is to make the reader understand queers. The book is not academic. The intended readers are teenagers. The book thus serves a double purpose in the course, both to make the students familiar with the lives of queer-identified persons and to present a book they themselves can use when they address the same topic in class. The choice to use the book in the course thereby reiterates the presumption that the students are unfamiliar with queer people or with queer desires and gender transgressions. In this way the experiences of queer-identified persons are placed outside the possible lived experiences of either the students and the teachers. They therefore have to 'meet' queer persons in the form of personal accounts. This means that the students are produced as heterosexual and in need of learning something about 'the other'.

The seminar where the book was discussed was predominantly arranged as a discussion where 'we', who were presumed to identify as heterosexual, discussed 'them', who identify as LGBTQI. The teacher introduced the discussion by stating that the group would have a round of questions, that is, giving room for everybody to ask their question one after another before the actual discussion would begin. But because the topic might make some students uncomfortable, the students were first write to down their questions and put them into a hat from which questions would be drawn and read out, so the askers would remain anonymous. In this way the topic of transgressions of the heterosexual norm emerged as different from almost all other topics where the importance of being responsible and able to present valid arguments is stressed. The topic of LGBT persons is thereby constituted as sensitive and as special. When the round began, the teacher wrote the questions on the whiteboard. The questions predominantly reiterated homotolerance, that is, the conception that, in Sweden, LGBTQI persons are entitled to tolerance. These were questions like 'How will we be able to be able to deal with pupils without expressing prejudice?'; 'How shall I make ordinary pupils tolerant towards those who deviate?', and the proposition 'In this occupation one needs to be open and liberal in relation to gender.' These and similar questions and propositions commonly presumed, and thereby also affirmed, a Swedish heterosexual normativity which produces LGBTQI subjects as 'others' in need of recognition and tolerance.

When discussing the question about how to make pupils tolerant of LGBTQI persons, several students suggested inviting activists from the Swedish Federation for 
Lesbian, Gay, Bisexual, Transgender and Queer Rights (RFSL) so that pupils could meet a queer person. One student claimed that this would be a good way to bring up sexuality in school, because in that way the pupils could experience that LGBT persons are 'normal, that they are ordinary people'. Another student agreed, saying that this would be a good way to do it, 'because you cannot know how it is unless you've experienced it yourself'. The strategy these students proposed contributes to constructions of LGBTQI as stable identities, as well as heterosexuality as stable. They assert that, unlike for most other subjects and topics in school, one cannot find information about sexuality and gender transgression unless one identifies as LGBTQI. In this way, both heteronormativity and the othering of everything outside the heterosexual norm becomes stabilised. Furthermore, the idea of using LGBTQIidentified informants in school so that pupils learn that LGBTQI persons are 'normal' expresses limits on how those representing the deviation should appear and talk. It not only produces heteronormativity, but also homonormativity, where homosexual desires and practices are disciplined and normalised by and within the nation as tolerable. Because, as Puar puts it, 'the nation is not only heteronormative, but also homonormative' (Puar 2005,50). Within this national frame, some queers emerge as better than others. The idea is that inviting effeminate gays or butch lesbians to speak in class would not be in the interest of the LGBTQI persons themselves, because they would confirm prejudices of pupils and pose obstacles to the sought-for tolerance of queers. The tolerance of LGBTQI identified persons is conditioned. In this way, the homonationalism produced in the classroom enforces traditional and stable gender roles and positions those who do not conform to these roles as intolerable.

The other in the form of the tolerable queer is consequently produced by positioning queer bodies outside classrooms and the university. This is accomplished by stressing the necessity to bring accounts of LGBTQI persons, or the persons themselves, into the school. It is further facilitated by staging a discussion where 'we' discuss 'them'. The outside, or vulnerable situation for queer bodies, is enforced by constructions of stable sexual minority identities that need to be tolerated by stable majority identities. Furthermore, in order to be tolerable, queer bodies have to represent themselves as normal and ordinary, that is, to align their gender and sexuality performance with dominant gender norms.

\section{Homonationalism - the other as the homophobe}

Not only LGBTQI persons were produced as others. The same process applied to those defined as homophobes or intolerant. In previous texts, I have discussed how 'the teacher' in 
these situations is produced as a self-evident good person who is without prejudices based on gender, class, ethnicity, or sexuality (Reimers 2007, 2008). The homotolerance performed in the seminars and at the theme day was produced by repeated reiterations of 'the teacher', and the teacher students, as self-evidently upholding the fundamental values of the curriculum. There were very few, if any, openings for expressing intolerance of queers.

In the course and at the theme day, most students willingly agreed that prejudice and discrimination against LGBTQI persons were unfounded, wrong, and a problem that the school needs to work against. They thereby affirmed the value of tolerance, and consequently constituted themselves as tolerant and therefore as having no part in marginalising and discriminating LGBTQI persons. The notion of the teacher was instead produced as a selfevident force against homophobia. The problem for maintaining homotolerance was thus placed outside teacher education and outside the teachers themselves. Homophobia and prejudice were made into individual problems and aberrations, not social or structural problems. In this way the notion of homonationalism was enforced.

At the theme day, this became obvious when the students were asked to have group discussions around 'Obstacles, possibilities, and requisites to implement LGBT perspectives in school.' The majority of the students participating were future preschool or primary school teachers, and the discussion immediately turned to homophobic or hostile parents who cannot accept having their children in the same group as children of LGBT parents or who cannot accept teachers who openly identify as LGBTQI. The teachers, on the other hand, were talked about as carriers of the fundamental norms of the curriculum, signified by attributing everybody the same value, tolerance, and equality.

A similar phenomenon emerged at a seminar focused on sexism in schools. Sexist practices and language in schools were here solely attributed to pupils. Sexism was made into problematic individual, or sometimes group, behaviour that needs to be disciplined. A suggested solution was that there should be 'more adults in school'. In this way, sexism was produced as lack of maturity, as a sign of immature masculinity. Although there were a lot of references to social norms and feminism as ways of understanding sexism, in these discussions teachers seemed to be positioned outside these norms. As in the theme day, teachers' position as representatives of the fundamental values of the Swedish national curriculum was fortified and never questioned. 
A teacher is a civil servant and thus a representative of the nation-state. Articulations of norms pertaining to the role of the teacher can therefore be understood as practices of banal nationalism. When teacher students repeat these norms by positioning themselves outside heteronormative practices and opinions that produce others, including both LGBTQI persons and those who are more or less homophobic, they not only perform homonationalism, they also obfuscate processes of marginalisation, discrimination, and precarisation. This was not least evident when the practices in the seminars and at the theme day reiterated conceptions about race and ethnicity in order to enforce the notion of a homotolerant Sweden.

\section{Homonationalism - the other as the migrant}

Nationalism, whether it is banal nationalism, homonationalism, or any other form of nationalism, constitutes the nation as both different and superior in relation to other nationstates. Specific for homonationalism is that attitudes towards LGBTQI persons are made into traits of the nation-state that sets it apart from other nations, cultures, or religions. In this way it produces 'us' as homotolerant and 'them' as intolerant, as well as 'us' as modern, and 'them' as obsolete.

In the seminars as well as the theme day, the topic of norms and attitudes towards sexuality and gender induced talk about migrants in relation to Swedes. Sexism and homophobia were framed as traits or problems upheld by migrants, whereas homotolerance, and being openly self-identified as queer was plugged in with Swedish-ness.

The question that the participants at the theme day decided was most important in relation to LGBT perspectives in school was 'How should we as teachers bring up LGBT issues in classes where we know that families see it as taboo?' In attending one group where this was discussed, it was apparent that the families they were referring to were migrant families. In this group, sexuality and gender were constructed together with culture. The students expressed that they lacked knowledge about what is and isn't okay in different cultures. They agreed that sexuality is a difficult topic as it is, and bringing it up to people from 'other cultures' makes it even more difficult.

A similar pattern was present in the seminar around the book People like Us (Mobacker 2003). When the students were asked to pick a chapter that had made the strongest impression, several mentioned a chapter about a gay couple where both partners came from migrant families. It is a chapter about secret love, because the men had to hide 
their relationship from their families. This gave rise to a discussion about the difficulties that LGBTQI migrants meet, and about how it is easier to identify and live as LGBT if one has a Swedish background. In this discussion migrant LGBTQI persons were produced both as different and vulnerable, which simultaneously produced Swedish LGBTQI persons as natural and safe. One student stated: 'It is almost impossible to be out if you're from another culture'. The 'normal' queer is thus a Swedish queer.

The same conception was also evident when a student at the theme day recounted her bewilderment and confusion when a senior student on their first day at the university presented himself at the student reception saying, 'My name is Mohammed and I am gay.' For her, this was a contradiction in terms. Gay and the name Mohammed were incongruous. The wide gap between Swedish and migrant cultural values in relation to sexuality was further enforced by a student who herself had a migrant background. She stated that for her, as Syrian, there could be a conflict between the fundamental values and the expectations that she be true to the values of the migrant group she belongs to. This was affirmed by another student with a similar background, who told a story about all the difficulties a gay man from the Syrian community met with in connection to his coming out. According to these two selfidentified Syrian students, there is no room for queer tolerance in the Syrian culture. In choosing to be open as LGBTQI, a person is simultaneously shut out from the Syrian community and his/her family.

The reiterations of this opposition between what is considered Swedish and what is considered migrant (or in this case Syrian) produces homogeneous conceptions of how LGBTQI people are regarded and treated within both migrant cultures and Sweden as a nation. It is a black and white dichotomy, with strong homophobia among migrants and a benevolent homotolerance among the Swedish. The opposition is so strong that rather than being subverted it comes forward in the accounts above as strengthened when students who, despite identification as Syrian, strongly align themselves with homotolerance and express disdain for what they say signifies the Syrian community. They constitute themselves as exceptions to the rule. Instead of subverting the conception of a homophobic Syrian culture, they come forward as Syrians who are slightly more Swedish than most Syrians, not least because they are studying to become teachers and, as such, representatives of Swedish values and culture.

The repeated articulations of migrants and migrant cultures as conflicting with Swedish values and cultures reiterates and affirms Swedish homonationalism in that sexuality 
becomes a signifier for nationality. In this way, Swedish heteronormativity and homophobia, both as mundane marginalisation and as explicit hate and discrimination, are obfuscated, or dismissed as non-Swedish. In the following I will discuss neoliberal educational discourses as aspects of Swedish homonationalism, which produces some subjects as more precarious than others, and how teacher education can approach homonationalism in order to change relations of precarity.

\section{Homonationalism as a differentiating power in education}

The enactments of homonationalism in teacher education accounted for above are all emerging from an assemblage where the liberal rights discourse is a strong line (or force). The motivation for bringing up LGBTQI as a topic within teacher education is the fundamental values in the introduction of the national curriculum. The formulation of these values reiterates formulations in the legislation against discrimination. This legal discourse, in turn, is based on a conception of discrimination related to social categories, and the idea is that no person should be discriminated against based on the category she/he identifies or is identified with. It is a human rights discourse. This is also a discourse that not only protects the rights of precarious subjects but simultaneously produces some subjects as precarious because they can be discriminated against.

In the observations, students used this rights discourse both to confirm and to make trouble with the notion of a relation between LGBTQI identification and precarity. In the seminar, one student was sceptical about categorising people based on sexual and gender identification as well as developing special strategies in order to affirm LGBTQI pupils. He claimed that 'we should not talk about this but treat everybody the same'. Thus his argument was that if we all adhere to a rights discourse where everyone is treated as equal, pupils will emerge as individuals and there will be no need to pay attention to sexuality and gender. He thereby repeated the neoliberal educational discourse present within the assemblage of Swedish homonationalism, in which each pupil is seen as an independent, rational individual whose learning and accomplishments are results of informed choices. In this discourse, categorisations such as class, gender, race, religion, ethnicity, and functionality are regarded as irrelevant for the learning and success of the pupil. What matters in this meritocracy is efforts, choices, and talents. The role of the teacher is thus to disregard aspects such as class, sexuality, gender, race, culture, and so forth. The same conception was reiterated when a student in one seminar spoke about the importance of teachers being neutral and objective, 
regardless if she/he identifies as woman, migrant, LGBTQI, or some other category. According to him, these categorisations are insignificant in the classroom.

Even if the above neoliberal conception of pupils and teaching could be apprehended as an alternative to homonationalism, in that LGBTQI identification is made insignificant, I claim that the neoliberal conception also reproduces homonationalism and produces queer bodies as vulnerable. As Butler asserts, the neoliberal discourse fails to recognise that not all subjects are equally recognisable and that 'the compulsory demand to appear in one way rather than another functions as a precondition of appearing at all' (Butler 2015, 35). The assertion that norms and categorisations are irrelevant for relations and practices in the classroom is a practice of banal nationalism, because the norms about what is considered normal in a Swedish school are present and productive whether they are recognised or not, producing pupils - and teachers - as more or less vulnerable based on norms pertaining to gender, sexuality, race, and/or functionality. Disregarding effects of norms does not make the norms disappear. As I have demonstrated above, recognising norms does not preclude productions of inequalities and marginalisation.

So how is it possible to train teachers to make schools more equal and open to different identifications and subject positionings? My proposition is to use homonationalism as a point of departure, and instead of focusing on the situation for those who are considered other, scrutinise the assemblage of homonationalism, how it is produced and enacted, and what it produces. This means that the construction of the nation in terms of values, history, dominant norms, habits, virtues, etc. needs to be a topic of study in itself. As Butler states, the emergence of subjects takes place in networks of relations. The primary condition for subjectivity is dependence on what she refers to as infrastructures consisting of people, materialities, politics, norms, etc. Homonationalism is an infrastructure which produces white and well-behaved LGBTQI persons as tolerable others, together with producing migrants as heteronormative threats to a presumed homotolerant modern and enlightened Swedish nation. The workings of this norm need to be investigated in teacher education. With teachers who are aware of the complexity of homonationalism, and how it works together with other norms, it becomes more possible to make schools places that offer infrastructures that will enable the emergence of multiple and varied subjectivities. Important here is to question the notion of teachers as positioned outside homonationalism and heteronormativity. There is no position outside norms, and there is no end point in the work of making way for new and more differentiated subjectivities. Assemblages are constantly changing and constantly 
productive. The task for the teacher is to be aware of how banal nationalism together with norms about gender and sexuality produce some bodies as more vulnerable than others - and to do something about it.

\section{Funding}

This paper is based on research from the project 'Heteronormativity - School as Space for Construction of Sexuality and Gender', funded by the Swedish Research Council.

\section{References}

Allan, Alexandra, Elizabeth Atkinson, et al. 2010. Speaking the unspeakable in forbidden places: Addressing lesbian, gay, bisexual and transgender equality in the primary school. Sex Education. 8: 315-328.

Anderson, Benedict. 1983. Imagined communities: Reflections on the origin and spread of nationalism. London: Verso.

Ball, Stepen J. 2006. Education, Policy, and Social Class. The Selected Works of Stephen J. Ball. London. Routledge.

Bengtsson, Jenny. 2013. Jag sa att jag älskade han men jag har redan sagt förlåt för det. Ålder, genus och sexualitet i skolans tidigare år. [Age, gender and sexuality in the early school years]. Linköping: Linköping University.

Billig, Michael. 1995. Banal Nationalism. London: Sage.

Brown, Wendy. 2015. Undoing the Demos. Neoliberalism's Stealth Revolution. New York: Zone Books.

Butler, Judith. 1990. Gender trouble. Feminism and the subversion of identity. New York: Routledge.

Butler, Judith. 1993. Bodies that matter. On the discursive limits of "sex”. New York: Routledge.

Butler, Judith. 2004. Undoing Gender. New York: Routledge.

Butler, Judith. 2015. Notes toward a performative theory of assembly. Cambridge, MA: Harvard University Press. 
Cavanagh, Sheila L. 2005. Sexing the teacher. Voyeuristic pleasure in the Amy Gehring sex panic. Social Text 23:11-134.

Cavanagh, Sheila L. 2006. Spinsters, schoolmarms, and queers: Female teacher gender and sexuality in medicine and psychoanalytic theory and history. Discourse: Studies in the Cultural Politics of Education. 27: 421-440.

Deleuze, Gilles and Guattari, Felix. 1987. A Thousand Plateaus: Capitalism and Schizofrenia. Minneapolis: University of Minnesota Press.

Epstein, Debbie and Johnson, Richard. 1998. Schooling sexualities. Buckingham: Open University Press.

Epstein, Debbie, O’Flynn, Sarah, Telford, David. ed., 2003. Silenced sexualities in schools and universities. Stoke on Trent: Trentham Books.

Ferfolja, Tania. 2007. Teacher negotiations of sexual subjectivities. Gender and Education. 19: 569-586.

King, James R. 2004. The (im)possibility of gay teachers for young children. Theory and Practice. 43: 122-127.

Kissen, Rita.M., ed. 2002. Getting ready for Benjamin: Preparing teachers for sexual diversity in the classroom. Lanham: Rowman \& Littlefield.

Kumashiro, Kevin, K., ed., 2001.Troubling intersections of race and sexuality: Queer students of color and anti-oppressive education. Oxford: Rowman \& Littlefield Publishers, Inc.

Lundgren, Anna-Sofia. 2008. Representing what? Aspects of the teacher's role in light of heteronormativity. In Norm-struggles. Sexualities in contentions, eds. Martinsson, Lena and Eva Reimers, 53-66.. Newcastle upon Tyne: Cambridge Scholars Publishing.

Luschen, Kristen V. and Bogad, Lesley. 2003. Bodies that matter: Transgenderism, innocence and the politics of 'unprofessional' pedagogy. Sex Education, 3:145-155.

Martinsson, Lena and Reimers, Eva. 2008. Towards a disharmonious pluralism: Discourse analysis of official discourses on social diversity. In Problematizing identity. Everyday struggles in language, culture, and education, ed. Angel M.Y. Lin, 51-65. London: Lawrence Erlbaum Associates. 
Martinsson, Lena and Reimers, Eva. 2014. Skola i normer. [A school(schooling) in norms]. Malmö: Gleerups.

Mobacker, Susanne, ed. 2003. Såna som oss. Röster om sexualitet, identitet och annorlundaskap.[People like us. Voices about sexuality, identity, and being different.] Stockholm: Tiden.

Puar, Jasbir K. 2005. Queer Times. Queer Assemblages. Social Text.23: 121- 139.

Puar, Jasbir K. 2007. Terrorist assemblages: Homonationalism in queer times. Durham: Duke University Press.

Puar, Jasbir K. 2013. Rethinking homonationalism. International Journal of Middle East studies, 45: 336-339.

Reimers, Eva. 2007. Always somewhere else. Heteronormativity in Swedish teacher training. In Norms at work. eds. Lena Martinsson, Eva Reimers, Jolanta Reingardé, and AnnaSofia Lundgren, 54-68. Stockholm: Under Ytan.

Reimers, Eva. 2008. Homotolerance or queer pedagogy? In Norm-struggles: Sexualities in contentions. eds. Lena Martinsson, Eva Reimers, 14-28. Newcastle upon Tyne: Cambridge Scholars Publishing.

Rich, Adrienne. 1993. Compulsory heterosexuality and lesbian existence. In The Lesbian and Gay Studies Reader, eds. Henry Abelove, Michele Aina Barale, David M. Halperin (Eds.), 227-254. New York: Routledge.

Røthing, Åse. 2008. Homotolerance and heteronormativity in Norwegian classrooms. Gender and Education. 20: 253-266.

Sahlstöm, Jenny. 2006. En utmaning för heteronormen - Lärares kunskapsbehov och ansvar inom områdena sexuell läggning och homofobi [Challenging heteronormativity teachers' need for competence on sexual orientation and homophobia]. www.ytan.se.

Seidman, Steven and Meeks, Chet. 2011. The politics of authenticity: Civic individualism and the cultural roots of gay normalization. Cultural Sociology. 5: 519-536.

SFS 2010:800. Skollag. [Education Act]. http://rkrattsdb.gov.se/SFSdoc/10/100800.PDF, retrieved 2016-04-22. 
Sherwin, Gary, and Jennings, Todd. 2006. Feared, forgotten, or forbidden: Sexual orientation topics in secondary teacher preparation programs in the USA. Teaching Education. 17:207-233.

Skolverket. 2011. Curriculum for the compulsory school, preschool class and the recreation centre 2011. Stockholm: Skolverket

Warner, Michael. 1993. Fear of a queer planet. Queer politics and social theory. Minneapolis: University of Minneapolis Press. 